Volume 8 , Issue 2

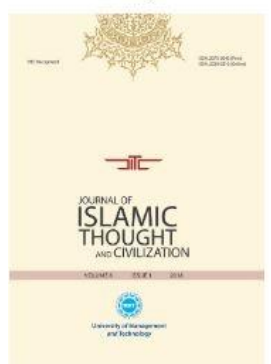

Journal of Islamic Thought and Civilization (JITC)

Volume 8, Issue 2, Fall 2018

ISSN: 2075-0943, eISSN: 2520-0313

Journal DOI: https://doi.org/10.32350/jitc

Issue DOI: https://doi.org/10.32350/jitc.82

Homepage: https://www.umt.edu.pk/jitc/home.aspx

Journal QR Code:
Article:

Author(s):

Online

Published:

Article DOI:

Article QR

Code:

To cite this article:

Copyright Information
Using Historical Islamic Sources to Promote Ethical Character

Jonathan Zartman

Fall 2018

https://doi.org/10.32350/jitc.82.01

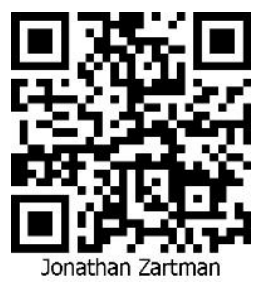

Zartman, Jonathan. "Using historical Islamic sources to promote ethical character." Journal of Islamic Thought and Civilization 8, no. 2 (2018): 01-16. $\underline{\text { Crossref }}$

This article is open access and is distributed under the terms of Creative Commons Attribution - Share Alike 4.0 International License

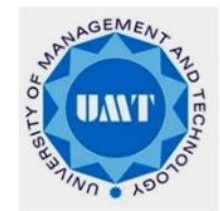

A publication of the

Department of Islamic Thought and Civilization

School of Social Science and Humanities

University of Management and Technology

Lahore, Pakistan.
Indexing Partners

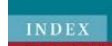

ISLAM I C US

Crossref

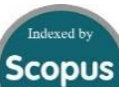

Scopus

(5) WorldCat

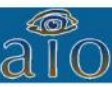

GENERALIMPACTFACTOR

INDEX COPERNICUS

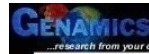

Gesearch from yourcestiop
Genamics Journal Soek

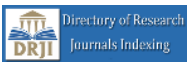

$\mathrm{R} \partial \mathrm{AD}=$

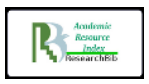

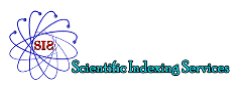

For more, please

click here 


\title{
Using Historical Islamic Sources to Promote Ethical Character
}

\author{
Jonathan Zartman* \\ National Security Studies \\ Department of Research and Publications, \\ Air University, USA
}

\begin{abstract}
This article provides a survey of the development of Islamic ethical literature. It argues that this literature promotes not only submission to Allah Almighty and the divine law, it also portrays ethics as a path that offers a peaceful inner life and elicits cooperative behavior from others. This article surveys the most significant literary forms currently available in Persian and English from the first six centuries of Islamic civilization produced in West, South and Central Asia that provide appealing sources of ethics. ${ }^{1}$ It demonstrates that the variations in style and format of this literature derives from the efforts of Muslim poets, viziers, teachers and scholars to overcome the political difficulties in challenging corruption, tyranny and oppression. It argues that this literature offers an antidote to antagonistic Western stereotypes of Islam and also provides inspiration to teachers, parents and active citizens throughout the world. This article is divided into three sections. The first section summarizes five reasons to study Islamic ethics, the second section goes on to define the term Islamic ethics and the third section explains the historical development of both Arabic and Persian as modern languages which were used to promote ethics. This background allows for the discussion in the body of the paper extolling the character and benefits of eight forms of literature taken in the historical sequence of their appearance. It concludes that this literature is of great value for people around the world; the more the non-Muslims learn of this literature, the more highly they will appreciate their Muslim neighbors for their ethical ideals and human values.
\end{abstract}

Keywords: ethics, Adab, Akhlāq, Hikmat, character, ideal values, enlightenment, advice for princes, literature

\section{Introduction}

The following survey focuses on the most prominent texts available in Persian and English that people in South and Central Asia cite as appealing sources of ethics. This survey explains the character and benefits of eight significant forms of Islamic ethical literature arranged according to the historical sequence of their development. These forms are: Ethics encoded in animal metaphors (Kalilah wa Dima), Miskawayh's

*Correspondence concerning the article should be addressed to Jonathan Zartman, National Security Studies, Department of Research and Publications, Air University, USA jkzartman@yahoo.com.

${ }^{1}$ Persian is used in the widest linguistic and cultural sense, which includes Muslims of many schools of legal interpretation, not only the area governed by the ancient Sassanid Empire, but also as spread by the Mughal dynasty as far as Bangladesh. Although some of the texts referenced here were first written in Arabic and later translated into Persian, the article focuses on texts available in both Persian and English. Attempting to survey the comparable literature in Turkish, Arabic, Urdu, Indonesian, and other major languages would obviously far surpass the scope available here.

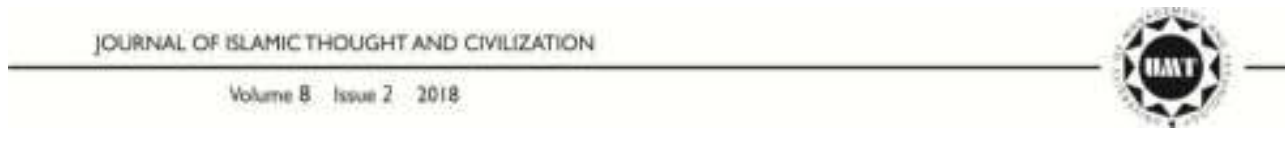


philosophical ethics, Morality veiled in mythology and history (Shahnama), The "Advice for Princes" literature, Al-Ghazali's Alchemy of Happiness, Morals in anthologies-Sa'di's wit and humor, The mystical morality of Rūmi and Kashifi's codification of ethics and philosophy.

Beginning from a brief summary of the benefits of the guidance, these texts provide for ethical character, it is argued that a review of the historical development of Islamic ethical literature reveals the high points and progressive nature of this ethical vision.

\section{Why Study the Islamic Ethical Literature?}

Islamic ethics developed over a long period of time in many languages. As the domain of Islam grew to include millions of people from different cultures from the second to the fifth centuries AH, Arabic and modern Persian also developed into literary languages as multilingual intellectuals worked to meet both the official and the popular needs of a changing society in a relatively cosmopolitan age. ${ }^{2}$ Hence, when Muslims reengage with their literary heritage, they can find a treasure trove of ethical values. To the extent that people today share the values promoted in this literature, they earn respect and build understanding with each other. In addition to the intrinsic and practical value of ethics, a deeper understanding of the ethical literature of the classical period of Islamic civilization offers the following benefits:

1) Ethics and character offer an antidote for the social pathologies afflicting many countries. Parents and school teachers need an attractive and enticing curriculum of ethics that reflects the honor of each country's history and literature. Teaching ethics through traditional literature can offer people hope in a way that avoids raising the fears of the governments that tightly regulate education. For example, children need an ethics curriculum that promotes those characteristics and qualities that enable success in professional life, such as resourcefulness, diligence, initiative, respect, punctuality, attentiveness, dependability, endurance, availability, and self-control. A curriculum of ethics based on traditional literature and history promotes citizenship. However, such a program only works with sincere intentions.

2) Given the ideological threat of radical militant groups, governments all over the world need ideas to discredit and delegitimize the ideology of rebellion and massacre. Many of the greatest minds of the Muslim world have committed their intellect toward this campaign to defend and present Islam in ideal terms. Therefore, a curriculum of ethics offers another sturdy tool to preserve Islamic civilization from the forces of anarchy. To defend against the militants accusing the government of jahiliyya, (the ignorance and barbarity of pagan Arabia before the coming of Islam) a government could wisely respond by promoting historically-grounded ethics that reflects its national traditions.

3) In an age in which westerners frequently hold and spread negative stereotypes of Muslims and fears of Islam, an understanding that Islamic history and literature reveals the highest ideals of humanity can inspire cross-cultural respect. This

\footnotetext{
${ }^{2}$ Dates generally provided in the format (Anno Hijra/Common Era).
}

2

JOURNAL OF ISLAMIC THOUGHT AND CIMLIZATION

Vulume 8 Issue 2 2018 
Zartman, Using Historical Islamic Sources to Promote Ethical Character

understanding provides a foundation for dialogue and reduces unnecessary antagonism. It also justifies using the classical Islamic history and literature as a source for ethics curriculum and instruction. The books on ethics relying only on the Qur'ān, Hadīth, and Sunna do not draw in the immediate and instinctive appreciation of people who lack the social context or background to identify with these sources. ${ }^{3}$ In other words, for those outside Islam, ethics can serve as a bridge to bring them into a position of respecting Islam and Muslims. The Persian literature of this classical period has proven its appeal to non-Muslim audiences. For example, consider Fitzgerald's popularization of the Rubaiyāt of Omar Khayyām.4 More recently, Rumi has become well-known in pop-culture circles in the West. ${ }^{5}$

4) Ethics plays a crucial role in leadership and management. For example, some NGOs seek to promote economic development by teaching a curriculum of leadership values as part of business management training. If the teachers use examples from the local history and literature, they would communicate respect and give honor to the heritage of their students which would increase their effectiveness as they build stronger interpersonal relations. For example, the principles of ethics that reflect self-control and respect for others receive easy acceptance and provide a foundation for other values which support economic development.

5) The principles of ethics provide guidance and support for people seeking ways to survive, adapt, and endure under the pressure of injustice. The classical literature written explicitly to advise rulers offers a great deal of guidance against corruption and oppression. Therefore, this literature is highly relevant today because the people in many majority-Muslim societies suffer from misgovernment and tyranny. The viziers, poets, and sages of Islam's classical age wrote for people who suffer, just like the millions today, struggling to survive while watching the conspicuous consumption of their ruling elites. Therefore, ethics represents a resource for change from the bottom-up.

For all of these reasons a greater understanding of the historical roots of ethics in Islam offers great value. The Islamic literature on ethical character includes a variety of genres and forms. Unfortunately, relatively few western scholars have explored this literature from the standpoint of the "cultural nationalists" and intellectuals who believe that their own history and literature offers all of the highest ideals of human enlightenment. ${ }^{6}$ The expression "high ideals" includes the ethical virtues that lead to intellectual creativity, social harmony, protection of human dignity and opportunity for a

\footnotetext{
${ }^{3}$ Camille Adams and Helminski Bath, eds., The Book of Character (England: The Book Foundation, 2004).

${ }^{4}$ Edward FitzGerald, “The Persian Sensation: 'The Rubáiyát of Omar Khayyám,' in the West” (Austin, TX: Harry Ransom Center, University of Texas, 2009). http://www.hrc.utexas.edu/exhibitions/ 2009/rubaiyat/. Accessed at: November 26, 2018.

${ }^{5}$ Rozina Ali, "The Erasure of Islam from the Poetry of Rūmi," The New Yorker, January 5, 2017. http://www.newyorker.com/books/page-turner/the-erasure-of-islam-from-thepoetry-of-rumi. Accessed at: November 26, 2018.

${ }^{6}$ Frederick S. Starr, Lost Enlightenment: Central Asia's Golden Age from the Arab Conquest to Tamerlane (Princeton: Princeton University Press, 2013), 519.
}

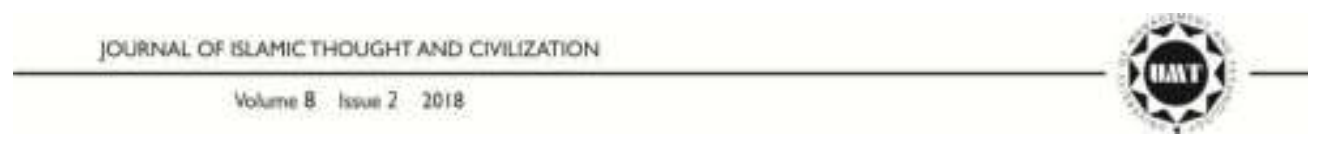


purposeful, satisfying life. For example, J. C. Burgel lauds the poetry of Nizāmi Ganjavi for promoting "non-violence, the dignity of women, the importance of personal development and self-knowledge, of true love, and, in general, humane behavior, inspired not by a legal code, but by reason and wisdom."7

Everyday businessmen, parents, and teacher and people in every walk of life can use ethics as a guide for wisdom and success. These ethical virtues do not come easily or naturally to anyone; indeed, their rarity and value makes them a treasure worth pursuing. These ethical qualities represent wisdom in terms of practical insight that protects someone from destructive behavior or attitudes and they also point the path to success in personal relationships. Whenever people find themselves struggling with their own emotions, their relationship with others or the progress of their work, they can ask themselves the question, "Am I thinking, acting and behaving in conformity to this principle of ethics and wisdom?" Despite the diversity of cultural life around the world, people generally recognize the practical value of wisdom and ethics.

Islamic literature offers examples of many specific virtues within three broad categories, self-control and submission to Allah Almighty, relations with other people and attitudes and habits of work. This literature builds on distinctive contributions from the Qur'ān, Hadīth, and Arabic-language proverbs and poetry.

\section{Defining Islamic Ethics}

Arabic literature provides the foundation of Islamic ethics. As the language of the Qur'ān, of the Prophet $(S A W)$ and his companions, and of all of the Muslim rulers for several centuries after the initial expansion of Islam, Arabic served as the first language of Islamic ethics. The role of ethics in Islamic literature can be explained by using two key Arabic terms. The first is Khuluq (plural Akhläq) meaning ethical character and the second is $A d a b$ which has a range of meanings centered around the idea of socially and morally proper behavior. Omar notes that to establish the Qur'ānic justification and understanding of ethics people commonly cite the phrase, "And you (Mohammad) have an exalted level of character." 8 The doctrine on this subject also derives support from Hadith such as the remark of the Prophet $(S A W)$, "The only reason I have been sent is to perfect good manners [Akhlāq];" and "the best among you are those who have the best manners and character." 10 Shukri argues that "a Muslim is expected to cultivate in himself the divine attributes-takhallaqu bi-Akhlaq Allah (cultivate in yourself the attributes of Allah)."11

Ethical behavior runs contrary to the natural inclination to seek material desires and status at the expense of others. Therefore, character development requires selfcontrol which is gained through training and disciplining from parents and teachers.

7Johan Christoph Burgel, "Acknowledgement," in A Key to the Treasure of the Hakim: Artistic and Humanistic Aspects of Ganjavi's Khamsa, eds., J. C. Bürgel and Christine van Ruymbeke (Leiden, The Netherlands: Leiden University Press, 2011), 7-9.

${ }^{8}$ Qur'ān: al-Qalam 68:4.

9 Imām Mālik, Muwatta Imam Maik, Book 47, Number 47.1.8.

${ }^{10}$ Bukhari, Sahih al-Bukhari, Vol. 4, Book "Merit of Sunnah," 56, Number 759.

${ }^{11}$ M. A. M. Shukri, "Towards an Islamic Theory of Literature," Islamic Studies 31, no. 4 (1992): 415 .

4

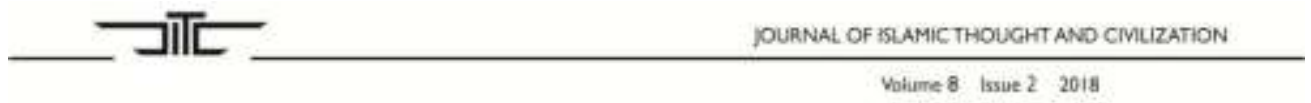


Advocates of morality propose a number of strategies for gaining the disposition, mental habits of mind and patterns of behavior that constitute ethical character. Reading specific forms of literature plays an important role together with the example, counsel and guidance of a moral teacher. This explains the multiple uses of the word $a d a b$ in addition to the primary meaning of ethical behavior; writers use $a d a b$ to describe a variety of forms of literature composed with the aim to promote praiseworthy social behavior. ${ }^{12}$ They further observe that works of $a d a b$ commonly represent "an anthology of good conduct and quotations suitable for social and literary discourse." 13 In sum, the adab literature reflects a long-term concern for cooperative social relations to promote the survival of one's family and society. Therefore, in addition to the vertical dimension of proper behavior, obedience and submission to Allah Almighty, ethical behavior requires conduct that demonstrates self-control, respect for others, especially teachers and those in authority as well as honorable diligence and conscientious fulfillment of one's duties at work, which encompasses the application of wisdom.

\section{Historical Development of Language and Ethics}

The Qur'ānic use of the term hikma or hikmat also indicates useful texts. The Islamic concept of ethics, built upon the Arabic heritage of wisdom literature, draws on a vast storehouse of ideas. Although this heritage initially resided in oral maxims and proverbs, later scholars have collected this hikma into books to document not only the virtues of Arabs and their accumulated wisdom but also the beauty and power of Arabic as a language. Webster explains the importance of proverbs in Arab culture and says, "Barakah suggests that, coupled with the reverence which Arabs have for their history and traditions, this respect for wisdom helps explain the frequency of proverb use in the culture, for the proverb is the linguistic embodiment of traditional wisdom."14

A summary of the books of Arab proverbs published over the years demonstrates the growth of this written culture. Riad Aziz Kassis has documented the development of collections of Arabic proverbs in Proverbs of the Arabs beginning from al-Mafaddal ibn Muhammad al-Dabbi (d. c. 170/786). The most comprehensive collection of 6,000 proverbs in thirty sections is compiled by Abu al-Fadl Ahmad b. Muhammad b. Ahmad b. Ibrahim al-Maydani al-Nishaburi (d. 518/1124). ${ }^{15}$ This documents the rich heritage of ethical wisdom that Arabs brought into Islamic culture.

Gutas argues that the great abundance and ubiquity of Arabic wisdom literature, with much of it taking the form of maxims, has inhibited scholarly attention to these

${ }^{12}$ Orfali and Baalbaki note that, "Recent scholarship has shown that adab constitutes a special kind of education, a moral and intellectual curriculum aimed at a particular urban class whose needs and aspirations it reflects." For detail see: Orfali, Bilal and Ramzi Baalbaki, The Book of Noble Character, Critical Edition of Makarim al-Akhlāq wa-mahasin al-adab wa bada'I al awsaf wa-ghara'ib al-Tashbihāt, attributed to Abu Mansur al-Tha'alibi (d. 429/1039Z, eds., Bilal Orfali and Ramzi Baalbaki (Boston: Brill, 2015), 2.

${ }^{13}$ Ibid.

${ }^{14}$ Sheila K. Webster, "Spicing the Conversation: The Development of Proverbs and its Role in Arab Culture," Al-Mashriq 2, no. 6 (2003). http://www.syriawide.com/spicing.html. Accessed at: November 11, 2018. 1999), 16.

${ }^{15}$ Riad Aziz Kassis, The Book of Proverbs and Arabic Proverbial Works (Boston: Brill,

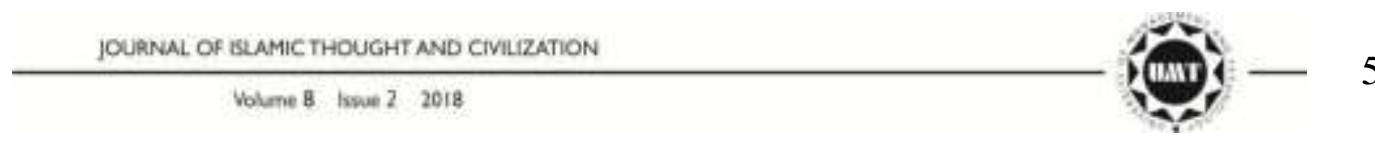


Zartman, Using Historical Islamic Sources to Promote Ethical Character

collections. ${ }^{16}$ He argues that in the early stages of the development of this literature the passion to preserve the unique and preeminent position of the Qur'ân led to some disparaging of wisdom literature. ${ }^{17} \mathrm{He}$ similarly claims that this commitment to preserving the status of the Qur'ān inhibited efforts to record hadiths. He furthermore notes that proverbs formed a significant part of Arabic poetry. So by its nature, the literature of Islamic ethics combines different forms of speech and writing. The combining of poetry, proverbs, maxims, anecdotes and sayings to form entertaining anthologies, the genre known as adab literature, was carried over into other languages such as Persian and persisted as a vehicle for conveying ethical guidance and wisdom for many centuries.

Over time, the expansion of Islam under the four Rightly Guided Caliphs, the Umayyad and the Abbasid dynasties necessitated employing scribes and secretaries to manage tax collection, send diplomatic messages, provide guidance to local governors and far-flung military commanders, and all of the assorted bureaucratic functions of a state. Shahid describes the beginning and development of Arabic literature as starting first with poetry followed by prose under the Umayyads. ${ }^{18}$ The increasing need for writers attracted Muslim converts from a Persian background who brought with them their understanding of, and access to, the Persian wisdom literature of counsels and advice. The Persians had already translated and adapted some Greek philosophical literature. Muslims from a Syriac heritage also translated and adapted Greek philosophical ideas into the new Islamic context. Therefore, the development of a large bureaucracy led to greater influence of Greek ideas as well as some Persian values and conceptions regarding ethical rule, which were synthesized into Islamic culture as a whole through Arabic language.

Marlow notes that Arabs used some Greek administrators in Egypt and Syria. Arabs had been living alongside Greeks in Syria for some time even before the Islamic conquest. After the conquest, Arab immigrants tended to settle among the native inhabitants. However, she concludes that Muslims adopted Greek ideals through the translation of texts rather than through contacts with Byzantine provincial communities. ${ }^{19}$ Gutas describes the process by which Muslims adapted new ideas to their existing repertoire of ethical and political concepts. He cites the example of Salim Abul-'Ala,' the secretary of the Umayyad Caliph Hishām b. Abd al-Malik (r. 105/724-125/743), who gained particular attention for promoting the translation and adaptation of Greek and Sassanian ethical and political literature. ${ }^{20}$ While the growing numbers of scribes under the Umayyads began to assess and adapt some Greek ethical and political ideas to meet the needs of governing an expansive empire, the work of translating Persian and Greek

\footnotetext{
${ }^{16}$ Dimitri Gutas, "Classical Arabic Wisdom Literature: Nature and Scope," Journal of the American Oriental Society 101, no. 1 (1981): 49.

${ }^{17}$ Ibid., 56.

${ }^{18}$ Shahid Irfan. "Arabic Literature," in The Cambridge History of Islam, Vol. 2, eds., P. M. Holt, Ann K. S. Lambton, and Bernard Lewis (Cambridge: Cambridge University Press, 1970), 661.

${ }^{19}$ Louise Marlow, Hierarchy and Egalitarianism in Islamic Thought (Cambridge, Cambridge University Press, 1997), 46.

${ }^{20}$ Dimitri Gutas, "Classical Arabic Wisdom Literature: Nature and Scope," Journal of the American Oriental Society 101, no. 1 (1981): 61.
} 
texts expanded greatly under the 'Abbasids (132/747-656/1258), particularly in the first two centuries of that caliphate. ${ }^{21}$

Shahid observes that after the overthrow of the Umayyads, the kuttāb, the chancery secretaries of the Abbasids greatly developed Arabic literature. He calls Rozbih Ibn al-Muqaffa, (d. c. 139/757) the famous secretary of the first Abbasid caliph Al Mansur, the most important author for the development of Arabic literature and culture. ${ }^{22}$ Although Ibn al-Muqaffa wrote and translated a great number of texts, Ketchichian reports that his works of $a d a b$ included political advice to the caliph and his courtiers." 23

However, Ibn al-Muqaffa deserves more recognition for translating from Pahlavi (Persian) the epic Kalilah wa Dimna, a set of animal stories that embody moral lessons. Despite the Indian origin of these stories, their enduring appeal - they were translated and adapted in many languages throughout the Islamic world - testifies to their utility for conveying moral lessons. No original Sanskrit or Pahlavi manuscripts for this compendium remain, so the Arabic version serves as the source text of the subsequent versions and translations. Therefore, Kalilah wa Dimna serves as the first important effort to promote an ethical vision. ${ }^{24}$ From Arabic, it was translated into New Persian in the mid-twelfth century CE by Nasrullah Munshi and further embellished by Husayn ibn Ali al-Wa'iz al-Kashifi in the mid-1400s under the name Anvār-i Suhayli (Lights of Canopus). ${ }^{25}$ The use of animals as embodiments of character traits provides a foil or a form of deflective protection from the anger of any ruler who would feel accused by a more direct approach in promoting ethical standards. The animal stories also add an attractive aesthetic quality. However, the symbolism brings in some ambiguity which requires creativity and interpretation by the teacher. For example, Jalal ad-Din Rumi used stories from this collection to promote his distinctively mystical mode of morality. ${ }^{26}$

In the time of Ibn Muqaffa (d. 139/757) and for the next hundred years other scholars adopted a directly religious approach to promote ethical values by documenting the reports and traditions of the Prophet $(S A W)$ (Hadith). Jurists used the hadith collections to develop a code of law expressed through four major Sunni schools of legal interpretation. These legal scholars-Imams Abu Hanafi, Malik ibn Anas, Abu Abdullah

${ }^{21}$ Cristina D'Ancona, "Greek Sources in Arabic and Islamic Philosophy," in The Stanford Encyclopedia of Philosophy, eds. Edward N. Zalta (Stanford, CA: Stanfor University Press, 2016), https://plato.stanford.edu/archives/spr2016/entries/arabic-islamic-greek/.

${ }^{22}$ Shahid Irfan, "Arabic Literature," in The Cambridge History of Islam, Vol. 2, eds., P. M. Holt, Ann K. S. Lambton, and Bernard Lewis (Cambridge: Cambridge University Press, 1970): 661 .

${ }^{23}$ Joseph A. Kechichian, “Abdullah Ibn Al Muqaffa: Words of Wisdom for the Kings," Gulf News, October 17, 2013. http:/gulfnews.com/life-style/general/abdullah-ibn-almuqaffa-words-of-wisdom-for-the-kings-1.1244087.

${ }^{24}$ Said Amir Arjomand, "Perso-Islamicate Political Ethic in Relation to the Sources of Islamic Law," in Mirror for the Muslim Prince, ed., Mehrzad Boroujerdi (Syracuse, NY: Syracuse University Press, 2013), 82.

25 Johan Christoph Burgel, "Acknowledgement," in A Key to the Treasure of the Hakim: Artistic and Humanistic Aspects of Ganjavi's Khamsa. eds., J. C. Bürgel and Christine van Ruymbeke (Leiden, The Netherlands: Leiden University Press 2011), 7-9.

${ }^{26}$ Said Amir Arjomand, "Perso-Islamicate Political Ethic in Relation to the Sources of Islamic Law," 82. 
Zartman, $\quad$ Using Historical Islamic Sources to Promote Ethical Character

al-Shafi'i, and Ahmad Ibn Hanbal al-Shaibani-all worked in the one hundred year period after Ibn Muqaffa.

Stefan Sperl argues that the Hadith compilations also represent an effort to promote ethical values and practices because all of them, except that of al-Nasa'i, contain a chapter devoted to $a d a b .^{27}$ His argument cites the shared aesthetic features and the openly avowed purpose of the hadith collections. Sperl recognizes the different orientations of Adab and Hadith, citing Khalidi, however, he also claims that both seek similar goals. For example, the anthology titled Adab al-Dunya wa "l-Din ("Adab of Worldliness and Religion") by the jurist al-Māwardi illustrates the common goal of promoting morality in both forms of books. ${ }^{28} \mathrm{He}$ observes that al-Māwardi quotes a broad variety of prophets, messengers, poets, and wise men to argue that a person who seeks to gain mastery over his own soul must acquire $a d a b$ by "assiduous practice and personal experience." 29 Therefore, the intentional organization of the reports into chapters based on the theme of a specific quality stimulates the critical thinking necessary to interpret the intent of each report and reveals a fuller understanding of the chapter.

While the traditionalists assembled the canonical Hadith collections and the jurists developed the four Sunni schools of legal interpretation during the Abbasid dynasty, the authority of the caliph became weaker at the expense of the military and that of the scholars and administrators. The Abbasid dependence on Turkic soldiers for their military eventually became a fatal weakness as the empire began to fragment under the assault of factious regional governors and ambitious generals.

For example, in the period between $876 \mathrm{CE}$ and $900 \mathrm{CE}$ the Saffarid dynasty which originated in the region of Sīstān (present-day south-east Iran) posed a grave threat to the caliph. In 900, Ismail Samani defeated Amr ibn Layth al Saffar causing the Saffarid Empire to collapse while the Samanids rose to power and rules Central Asia for the next hundred years from their seat of power at Bukhara. Until the rise of the Samanids, Arabic served as a universal language for the Islamic world. The Samanids promoted the development of a New Persian language using a modified Arabic alphabet and adding a great deal of Arabic vocabulary. ${ }^{30}$ Samanid patronage supported Rudaki (d. 330/940), the father of Persian poetry. ${ }^{31}$ The Samanid vizier Bal'ami composed a selective Persian adaptation of the Arabic history by al-Tabari. He began a trend in Persian chronicle writing of authors employing a great deal of literary stylistic freedom including personal criticism of rulers and important political people. ${ }^{32}$ Most importantly,

${ }^{27}$ Stefan Sperl, "Man's 'Hollow Core': Ethics and Aesthetics in Hadith Literature and Classical Arabic Adab,” Bulletin of SOAS 70, no. 3 (2007): 461.

28 Ibid., 465.

${ }^{29}$ Ibid.

${ }^{30}$ Ehsan Yar-Shater, "Persian Literature," in The Cambridge History of Islam Vol 2, eds., P. M. Holt, Ann K. S. Lambton and Bernard Lewis (Cambridge: Cambridge University Press, 1970), 671.

Ibid., 672.

${ }^{32}$ Bert G. Fragner, "Traces of Modernisation and Westernisation? Some Comparative Considerations concerning Late Bukharan Chronicles," in Reason and Inspiration in Islam: Theology, Philosophy and Mysticism in Muslim Thought, ed., Todd Lawson (New York: I. B. Taurus, 2005), 546. 
under the Samanids, Abu'l Qasim Ferdowsi Tusi (329/940-416/1025) began composing the Shahnama, a distinctively Persian epic poem combining mythology and history.

In 334/945, the Shiite Buyids threatened the Abbasid Empire and took control of Baghdad. This increased the clearly apparent bifurcation of sovereignty between caliphs who remained nominally in control of the sharia (religious law) and the political order seized by the military leaders of various regions who took the title "Sultān." Arjomand proposes a "theory of two powers" - of prophecy and kingship-reflected in the medieval literature on statecraft and kingship. Viziers and intellectuals felt compelled to propose historical and normative justification for the evolution of the obviously monarchic political system. ${ }^{33}$ This evolution played a crucial role in the development of philosophical ethics and the Islamic "advice for princes" literature, examined below.

Shahid argues that the rise of the Buyids created a de facto split between a Persian-speaking East and an Arabic-speaking West, although many Persians still wrote prose in Arabic. This discussion will leave to others the development of Arabic ethical and moral literature in Syria, Egypt, Sicily, and Spain, to focus on the development of ethics and moral literature in Persian-dominated areas in both Arabic and Persian languages.

Building on one hundred and fifty years of Islamic adaptation of Greek and Persian ideas, a vizier and ultimately a treasurer under the patronage of the Buyids named Abu 'Ali Ahmad Miskawayh (320/932-421/1030) contributed the next major pillar of Islamic ethics. His philosophical work on ethics Tahdhīb al-Akhlāq (The Refinement of Character) provides a clear and a logical arrangement of its components. This noble philosophical treatise expounds a rational argument for developing moral habits and overcoming vices. Miskawayh justifies the pursuit of ethical character as the fulfillment of the human calling to exercise our rational capabilities. For example, he describes the plant and animal world as ranging in status according to increasing capabilities, freedom of choice, and receptivity to training. Similarly, people who purposefully seek education to develop their ethical character gain the highest rank and status among humanity.

A good portion of this book offers motivation and justification for pursuing moral life. Although it employs pious explanations, religious arguments and a desire for spiritual power as the capstone of motivations, the book as a whole emphasizes the philosophical argument. As such, he recognizes that the mass of uneducated people will not be able to appreciate his claims pitched at an intellectual level. Instead, he seeks to stir up the worthy minds of those who desire and strive to attain the moral life. He carefully defends the pursuit of happiness as the ultimate good or goal but he defines happiness in sharp contrast to the pleasures of satisfying biological appetites or passions such as the desire for honor or revenge. Instead, he defines happiness as living a life in fulfillment of our highest capabilities.

In other words, happiness comes from using the rational mind to control the appetites and selfish passions, loving others and seeking the success of others, pursuing knowledge as a step toward wisdom and ultimately gaining receptivity to wisdom

\footnotetext{
${ }^{33}$ Said Amir Arjomand, "Perso-Islamicate Political Ethic in Relation to the Sources of Islamic Law," in Mirror for the Muslim Prince, ed., Mehrzad Boroujerdi (Syracuse, NY: Syracuse University Press, 2013), 85.
}

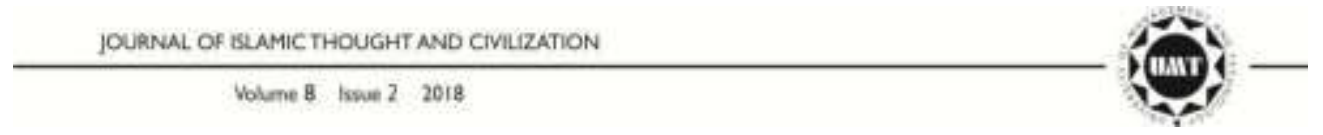


bestowed by Allah Almighty. ${ }^{34} \mathrm{He}$ argues that the ethical life leads to acting wisely which brings success, status, and honor. The ethical life means drawing closer to Allah Almighty and ultimately gaining insight that fills the heart with joy.

Miskawayh offers a very organized, top-down approach in which his definition of happiness leads him to designate four eminent virtues which are wisdom, temperance, courage, and finally, justice, as the ultimate balance among all of these exalted qualities. He enumerates six supportive virtues under wisdom, twelve secondary virtues under temperance, eight virtues under courage, six components of liberality, and eight parts under justice. Critics of Miskawayh accuse him of merely synthesizing Plato, Aristotle, as well as Stoics, Galen, and commentaries on these writers. However, by interpreting these writers in a new and unique way, to support Islamic beliefs and values, he raised the knowledge and aspirations of Muslim intellectuals who followed him and provided a foundation for their own works of synthesis and analysis. He put these ideas to practical use by applying them to current conditions and problems. Therefore, Miskawayh has contributed the second key pillar of the literature of Islamic ethics.

This book deserves greater recognition for the intrinsic value of its argument and also because it served as foundation for subsequent efforts over the centuries. Abu Hamid al-Ghazali (c. 450/1058-505/1111) used it in his Arabic Ihya' 'Ulüm al-Dìn (The Revivification of Religion), and so did Nasir al-Din al-Tusi (672/1274) in Akhlāqi Nasiri, and Jalal al-Din al-Dawwani (908/1502) in Akhlāqi Jalāli. ${ }^{35}$ The following historical setting provides the context to understand the contributions of these men.

Both the Buyids and Samanids fell and their failures in governing motivated popular rebellions. The Samanid military forces would capture young Turkic boys on raids and raise them in the military, where, through their political and military abilities some rose to positions of power. One of these slave generals, Alptegin, and then his sonin-law Sabuktegin, established de facto independent states and ultimately an empire in Ghazni. The Ghaznavids recruited talented intellectuals from other competing royal courts. For example, Ferdowsi shifted his allegiance and sought the patronage of Mahmud of Ghazni for his epic historical poem. His book represents the third major pillar of Islamic ethics from a Persian cultural point of view.

Nasrin Askari examines the way in which the Iranians received the Shahnama and the way in which the writers afterwards employed excerpts and fragments of it. She concludes that in contrast to the modern tendency to only see its literary value or to analyze it for historical insight, Ferdowsi's readers in the centuries following understood it as an ethical/didactic text. However, this requires familiarity with the language of metaphor and symbol. For centuries after its creation, writers produced selections from the Shahnama to emphasize its value as a book of wisdom and advice. ${ }^{36}$ All of her

${ }^{34}$ Abu 'Ali Ahmad ibn Muhammad Ibn Yaqub Miskawayh, The Refinement of Character (Tahdhīb al-Akhlāq), trans., Constantine K Zurayk (Chicago: Great Books of the Islamic World, 2002), 63-77.

${ }^{35}$ Mohd Nasir Omar, "Ethics in Islam: A Brief Survey," The Social Sciences 8, no. 5 (2013): 391; Maria E. Subtelny, "A Late Medieval Persian Summa on Ethics: Kashifi's Akhláq-i Muhsinı," Iranian Studies 36, no. 4 (Dec 2003): 604.

${ }^{36}$ Nasrin Askari, The Medieval Reception of the Shāhnāma as a Mirror for Princes (Toronto: University of Toronto Press, 2016), 3. 
analysis points to Ferdowsi's intention to make his text as interesting as possible. While offering great value in teaching, he also wanted to entertain and educate and not merely to record history. She compares Shahnama to nine medieval Persian books giving advice for princes which reveal a consistent set of principles despite differences in cultural contexts, styles of writing, and the writers' social and professional background. In sum, Askari demonstrates that the Shahnama offers value in promoting ethical values to people across the broad Persian-language area. Shahnama not only represents a distinctive approach to teaching ethics, it also serves as the transition to literature written explicitly as "advice for princes."

The literature of advice for rulers developed in response to a fresh political challenge from the nomadic Central Asian group known as the Seljūqs Turks, who had become Muslim and adopted Persian as the language of their court. They gradually took territory and power from the Ghaznavids, eventually taking all of Iran, the Iraq, parts of the Levant, Armenia and Azerbaijan, and a good part of Anatolia. The secretaries and members of the bureaucratic class of the defeated rulers found jobs in the royal courts of the Seljūqs. For example, Abu Ali Hasan ibn Ali Tūsi worked for the Ghaznavids but shifted allegiance to the Seljūqs and became a vizier (like a Prime Minister). He served in that position from 1063-1092. He was given the name Nizām al-Mulk and wrote Siyasat Nāma (Book of Politics). ${ }^{37}$ He established a number of colleges called Nizāmiyya in his honor to promote Sunni Islam in opposition to the rival power of the Ismaili Fatimid dynasty ruling from Egypt. The Fatimids had established the Al-Azhar University to train preachers $\left(D^{\prime} i\right)$ to promote Ismaili doctrine. The political and military power of the Fatimids reinforced the ideological challenge presented by the well-trained advocates for their doctrine which motivated the Seljūq desire for creating competing institutions of education.

One of the subordinate vassals of the Seljūqs, the Prince of Gurgan Kai Kavus Ibn Iskandar, wrote a book of political advice for his son called the Qabūs Nama. ${ }^{38}$ Under the patronage of Nizām al-Mulk, the theologian and jurist al-Ghazali wrote extensively. He engaged in polemics against the Ismailis and wrote Nasihat al-Mulūk (Guidance for Kings). ${ }^{39}$ These three texts, Siyasat Nama, Qabūs Nāma, and Nasihat alMulük represent preeminent examples of literature designed to give advice to rulers, which analysts in the European context frequently call "Mirrors for Princes." They reflect the tension between the behavior of the sultāns versus the ethical and moral ideals of the Persian-Islamic synthesis held by the bureaucrats and court officials.

These officials blamed some residual nomadic and Turkic values for the oppression and corruption of the rulers. Therefore, in their corrective guidance they cited Islamic scripture and examples of early Muslim leaders as well as the virtues of idealized, even mythological, Persian kings. In the perspective of these court officials, the cruel oppression of the rulers provoked the opposition and anger of Allah who enabled

\footnotetext{
${ }^{37}$ Nizam Al-Mulk, The Book of Government or Rules for Kings: The Siyār al-Mulūk or

Siyasat-Namah, trans. Hubert Darke (London: Routledge and Kegan Paul, 1978).

${ }^{38}$ Kaika'us Iskandar, A Mirror for Princes: The Qabūs-nama, trans. Reuben Levy (London: Cresset, 1951).

${ }^{39}$ Muhammad Al-Ghazali, Ghazali's Book of Counsel for Kings (Nasihat al-Muluk), trans. F. R. C. Bagley (London: Oxford University Press, 1964).
}

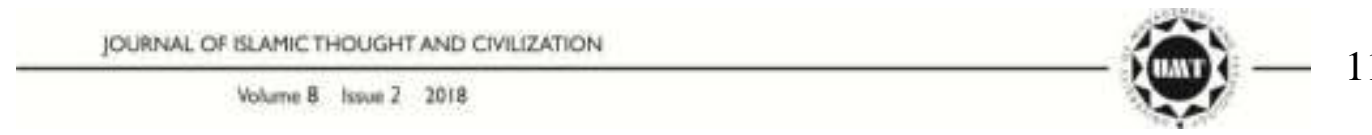


peasants and ambitious governors to revolt as their punishment. Therefore, they wanted the rulers to act justly to preserve their rule. These works appeal to three motivations:

1. fear of the judgment of Allah Almighty

2. pragmatic concern to avoid provoking or allowing revolt

3. the desire for honor and praise

These three works offer a frank presentation of the behavior that would lead to success as a ruler. Because these books reflect the cultural values of the times, they include topics that inspire revulsion today, such as "how to buy a slave." However, these books do offer value when considered at the higher level of general principles. For example, the Siyasat Nāma of Nizām al-Mulk repeatedly and emphatically teaches the importance of confirming every piece of information, checking and assessing all of the work of subordinate officials, and maintaining systems of quality control over all government employees to prevent corruption. He provides clear guidance that the Sultān must give people the opportunity to present their complaints, maintain a personal reputation for performing religious rituals, learn from and support educated people, and listen to people with experience. In sum, because these three works of advice for rulers convey detailed prescriptions for preventing oppression through personal integrity and diligence, they represent the fourth pillar in the foundation of the ethics literature.

During the time of Seljūqs, the theologian al-Ghazāli not only wrote Nasihat alMulūk and The Revivification of Religion, but also a Persian language book called Kimiya-yi Sa'adat (The Alchemy of Happiness) containing many parallel passages to The Revivification but tilting more directly in the direction of $a k h l a q q$ and $a d a b$. Much of the akhlāq orientation comes in the first four chapters to which The Revivification has no corresponding chapters. Zurayk notes that al-Ghazali introduced a philosophico-ethical element into religious tradition which later dominated Sunni thought. ${ }^{40}$

The Kimiya offers guidance for overcoming vices such as anger, hatred, jealousy, worldliness, greed, pride, vanity, deception, hypocrisy, fearfulness, and love of status and wealth. He follows this with advice for cultivating important virtues such as self-control, repentance, charity, patience, gratitude, hopefulness, truthfulness and sincerity, dependence on God, and courage in the face of death. ${ }^{41}$ However, al-Ghazali goes beyond the commonplace by using effective metaphors and analogies to inspire the reader to pursue his highest calling of worshiping Allah which requires self-control, rejection of fleshly lusts, pride, and anger. His discussion of gaining discernment between thoughts that will lead to noble actions and character as opposed to all of their unworthy deceptive imitators demonstrates why this text constitutes the fifth strong pillar for Persian ethical literature. ${ }^{42}$

${ }^{40}$ Constantine K. Zurayk, "Preface," in The Refinement of Character (Tahdhīb al-Akhlāq) (Beirut: American University of Beirut, 2002), xviii.

${ }^{41}$ Elton L. Daniel, "Preface," in Abu Hamid Muhammad al-Ghazzāli, The Alchemy of Happiness (Armonk, New York, 1991), xlii-xliii.

${ }^{42}$ Muhammad Al-Ghazali, Ghazali's Book of Counsel for Kings (Nasihat al-Muluk), trans. F. R. C. Bagley, (London: Oxford University Press, 1964), 74. 
Hillenbrand claims that the Kimiya provided inspiration for a variety of different works, from the Bahr al-fava'id to those of Jalal al-Din Rūmi. ${ }^{43}$

The rule of the Seljūqs marked a high point in the development of Persian as the language of the court. However, beginning in $1219 \mathrm{CE}$, the Turko-Mongol invasions threw the Persian world into turmoil. These armies slaughtered millions as they destroyed cities and their libraries - a horrendous loss for civilization and for the cultural heritage of the Islamic world. The educated strata of the population did not escape. In these conditions of upheaval, a Sufi poet, well-educated in Islamic theology, history, literature, and law, called Sa'di Shirāzi (c. 580/1184-691/1291) left Baghdad and traveled widely through the Levant, Anatolia, India, and Arabia. He returned to his native Shirāz in 1257 CE. The next year the Mongols destroyed Baghdad. Intellectuals, such as Sa'di reacted to the massive destruction wrought by the Mongols by turning inward to mysticism and adopting the political philosophy of quietism. Therefore, poetry with an ethical message, capable of multiple meanings, provided a way to promote morals in a politically safe way.

In contrast to his poetic work Būstān (The Orchard), Sa'di wrote a likewise famous work, mostly in prose, called Gulistān (The Flower Garden) which consists of a series of anecdotes that present moral lessons. According to Arjomand, Sa'di created the epitome of Persian ethical literature. ${ }^{44}$ Persian speakers argue that Sa'di greatly surpassed his peers in skill, appeal, and effectiveness. Because he freely employed Persian words with more than one meaning, his writing enables metaphorical and mystical interpretations.

However, the purity of his humanistic impulse comes through clearly. He wrote with an emotionally engaging style that forces his readers to confront their attitudes and prejudices. The text frequently rebukes the hypocrisy of the ostentatiously religious as well as the callous corruption of rulers. His advocacy of devotion to Allah and loving people makes his writing a brightly shining star in the ethical literature and earns this work the status ${ }^{45}$ of being the sixth strong pillar of ethics for the Persian-language cultural world. Sa'di also wrote a small book called Pand-namah or "Book of wisdom." 46 This simple but emotionally effective text pleads for sixteen different virtues, often using a contrasting moral defect to strengthen his case.

Sa'di lived at the same time as another superstar of the poetic heavens Jalal adDin Rūmi (603/1207-671/1273). Although Rūmi enjoys more fame for his expressions of mysticism, love and ecstasy, he also promoted a humanistic, ethical vision. For instance, he reinterpreted the stories of Kalilah wa Dimna to explain the wisdom and moral values embedded in the stories. Van Ruymbeke notes that Rumi adds a great deal of dialogue

${ }^{43}$ Carole Hillenbrand, "A Little Known Mirror for Princes by Al-Ghazali," in Words, Texts and Concepts Cruising the Mediterranean Sea, eds., Rudiger Arnzen and Jorn Thielmann (Leuven: Peeters, 2004), 601.

${ }^{44}$ Said Amir Arjomand, "Perso-Islamicate Political Ethic in Relation to the Sources of Islamic Law," in Mirror for the Muslim Prince, ed., Mehrzad Boroujerdi (Syracuse, NY: Syracuse University Press, 2013), 91.

${ }_{46}^{4}$ Ibid.

${ }^{46}$ Muslih-ud-din Sadi, Sa'di's Scroll of Wisdom, trans. Arthur N. Wollaston (London: John Murray, 1906). 
between the animals "packed with an exhilarating wit" which pays "attention to psychological plausibility and attention to verisimilitude." ${ }^{47}$ However, she also criticizes Rūmi for introducing disorder into the story line, in part due to frequently interjecting mystical interpretations. For example, he emphasizes the moral importance of selfcontrol, reliance on Allah Almighty, and more importantly, not projecting our own faults unto others.

The poetry of Sa'di and Rūmi does not just provide a spiritual or esoteric perspective on how to gain enlightenment or live a fulfilling and meaningful life encoded in the specialized vocabulary of the Süfis. The beauty of these works as emotional expressions of the human heart inspires self-understanding. The specialized vocabulary provokes moral curiosity, intriguing the reader to apply powers of insight and discernment, overcoming apparent conundrums that serve to screen out the casual, uncommitted reader from the devotees of pure truth. The ethical power of Rūmi's poetry has endured the passing of time and cultural differences, so his work deserves recognition as the seventh pillar of Persian ethical literature.

Over time, the Turkish and Mongol rulers accepted Islam and adopted Persian language and culture, due to their need for administrators to manage the local population and collect taxes. After a period of hundred and fifty years their system of rule decayed and fragmented. For example, a bandit from present-day south-eastern Uzbekistan called Timūr, through political skill and strategic prowess as a military commander, challenged one neighboring ruler after another and built an empire. Known in the West as Tamarlane, he fought almost all of his wars against other Muslims after declaring their governance deficient. His massive slaughter of millions seemed like a reprise of the conquests by the Mongols with a major difference; he searched for men of artistic skill and intellectual ability and took them as captives to make his capital of Samarkand a center of civilization.

The middle and later stages of the Timūrid Empire (771/1370-912/1505) produced another brief flowering of Persian language and culture. The great, great, grandson of Timūr, Sultan Husain Bayqara hosted a writer in his court Husayn al-Wa' is Kashifi (840/1436-910/1505), who left us an eighth pillar of Persian ethical literature. He not only created a new Persian translation of Kalilah wa Dimna, titled Anwar-e Suhayli (Lights of Canopus); he also wrote a very pure, noble exposition on morality called Akhlāqi-Muhsini (The Morals of the Beneficent). Subtelny argues that Kashifi wrote this in 907/1501/02, a time she calls the cultural highpoint of Timūrid rule in Khurasān but also the end of this rule because then Uzbeks the invaded. ${ }^{48}$ She calls Akhlāqi-Muhsini a summary, a compendium, and a codification of the Akhlāqi-Nasiri of Nasir al-din Tūsi, also resembling that of Jalal al-Din Davvani (Akhlāqi Jalāli) (872/1467-882/1477). With forty chapters, each developing a different theme or virtue, this work marks a very high advance in ethical literature compared to earlier works. Some of these chapters give

\footnotetext{
"Johan Christoph Burgel, "Acknowledgement," in A Key to the Treasure of the Hakim: Artistic and Humanistic Aspects of Ganjavi's Khamsa, eds., J. C. Bürgel and Christine van Ruymbeke (Leiden, The Netherlands: Leiden University Press, 2011), 97-98.

${ }^{48}$ Mohd Nasir Omar, "Ethics in Islam: A Brief Survey," The Social Sciences 8, no. 5 (2013): 391; Maria E. Subtelny, "A late medieval Persian Summa on Ethics: Kashifi's Akhláq-i Muhsinı," Iranian Studies 36, no. 4 (Dec 2003): 602.
} 
advice more applicable to rulers than the everyday worker, such as "The treatment of courtiers" and "Punitive ability." However, the inclusion of virtues necessary for economic development and success in business, such as "prudent foresight" "seizing opportunities" and "careful deliberation" gives this book more depth and thoroughness than preceding examples. Kashifi's thoroughness, insight, and skill of expression merit his inclusion as the eight pillar of Islamic ethics. After the fall of Sultan Bayqara, scholars in other regions, such as in India under the Mughals, and working in other languages such as Urdu, continued the development of Islamic ethics.

In sum, the contributions of the authors reviewed here convey an Islamic perspective on the ethical life, not only as submission to Allah Almighty and divine law, but also a path worth pursuing because it allows for a peaceful inner life and elicits cooperative behavior from others. For example, although people can extract material benefits from others using unethical behavior, the wise man notes that this creates anger that leads the victims to seek revenge. The incorporation of a rational, philosophical perspective into Islamic ethics builds on the recognition of the social nature of humanity, not merely out of interdependence due to the demands of survival in a harsh environment and the distribution of skills among the population. Human beings demonstrate their intrinsic social nature in their efforts to create beauty, employ symbolism, and express purpose in life, as seen in the development of cities, art, and religion in all societies. People express the power and benefits of ethics in beautiful writing, full of symbolism, as the key to success in ruling, leadership and management of people. Lois al-Farūqi expresses the point that ethics provides tools people need to solve practical problems.

There are social, political and economic decisions which contemporary Muslims must make, and unless they draw on the true sources of their religion and tradition in the effort to solve the problems confronting them, they will flounder in a sea either of cultural dissolution or dogmatic conservativism. ${ }^{49}$

The destructive consequences of "cultural dissolution" can be seen in the rootlessness and alienation of young second-generation diaspora Muslims searching for affirmation of their identity and purpose in life, which raises their vulnerability to radical recruitment. The evils of "dogmatic conservatism" can be seen in the tyranny of so many Muslim states that fail to provide justice and economic opportunity for their people, driving them also to seek solutions offered by the way of insurgency and rebellion.

\section{Conclusion}

The historical Persian literary sources of guidance in ethics take a broad variety of literary forms, from the animal metaphors of Kalilah wa Dimna to the coherent, rational philosophical approach of Miskawayh, to the pure, noble poetry of Sa'di and the mystical morality of Rumi, to the essays of advice explicitly directed at rulers and the compendiums of al-Ghazāli or al-Kashifi. These sources require the guidance of a moral teacher to help students find the kernel of ethical wisdom in the source and avoid the husk of historical context which might prevent them from extracting a benefit. The animal metaphors require wise insight to analyze the various lessons they offer. The poetry of Sa'di and Rūmi benefits from linguistic insight to reveal the higher levels of

\footnotetext{
${ }^{49}$ Lois Lamiya al-Faruqi, Islam and Art (Islamabad, Pakistan: National Hijra Council, 1985), 414.
}

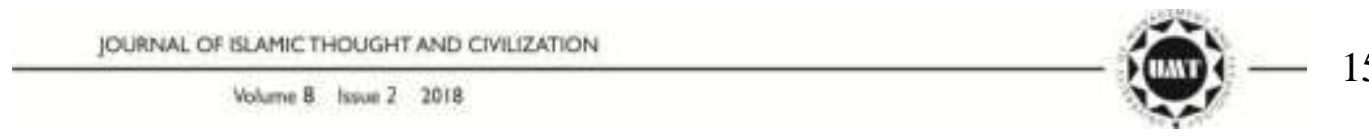


Zartman, Using Historical Islamic Sources to Promote Ethical Character

implied meanings. Therefore, all of these texts provide resources from which teachers and parents can extract teaching lessons in practical ethics.

\section{Bibliography}

Ali, Rozina. "The Erasure of Islam from the Poetry of Rumi." The New Yorker. January 5, 2017. http://www.newyorker.com/books/page-turner/the-erasure-ofislam-from-the-poetry-of-rumi.

Arjomand, Said Amir. "Perso-Islamicate Political Ethic in Relation to the Sources of Islamic Law." In Mirror for the Muslim Prince. Edited by Mehrzad Boroujerdi. Syracuse, NY: Syracuse University Press, 2013.

Askari, Nasrin. The Medieval Reception of the Shāhnāma as a Mirror for Princes. Toronto: University of Toronto Press, 2016.

Barakat, Robert A. A Contextual Study of Arabic Proverbs. Helsinki, Finland: Suomalainen Tiedeakatemia, 1980.

Burgel, Johan Christoph. "Acknowledgement." In A Key to the Treasure of the Hakim: Artistic and Humanistic Aspects of Ganjavi's Khamsa. Edited by J. C. Bürgel, Christine van Ruymbeke. Leiden, The Netherlands: Leiden University Press, 2011: 7-9.

Chittick, William C. "Worship." in The Cambridge Companion to Classical Islamic Theology. Edited by Tim Winter. 218-236. Cambridge: Cambridge University Press, 2008.

D'Ancona, Cristina. "Greek Sources in Arabic and Islamic Philosophy." in The Stanford Encyclopedia of Philosophy. Edited by Edward N. Zalta. Stanford, CA: Stanford University Press, 2016. https://plato.stanford.edu/archives/spr2016/entries/arabicislamic-greek/.

Daniel, Elton L. "Preface." In Abu Hamid Muhammad al-Ghazzali. The Alchemy of Happiness. Armonk. New York: 1991: xi-xxxix.

al-Faruqi, Lois Lamiya. Islam and Art. Islamabad, Pakistan: National Hijra Council, 1985.

Fragner, Bert G. "Traces of Modernisation and Westernisation? Some Comparative Considerations concerning Late Bukharan Chronicles." In Reason and Inspiration in Islam: Theology, Philosophy and Mysticism in Muslim Thought. Edited by Todd Lawson. 542-565. New York: I. B. Taurus, 2005

al-Ghazāli, Muhammad. Ghazāli's Book of Counsel for Kings (Nasihat al-Mulūk). Translated by F. R. C. Bagley. London: Oxford University Press, 1964.

Gutas, Dimitri. "Classical Arabic Wisdom Literature: Nature and Scope." Journal of the American Oriental Society 101, no. 1 (1981): 49-86.

Hillenbrand, Carole. "A Little Known Mirror for Princes by Al-Ghazali." In Words, Texts and Concepts Cruising the Mediterranean Sea. Edited by Rudiger Arnzen and Jorn Thielmann. 593-601. Leuven: Peeters, 2004.

Iskandar, Kaika'us b. A Mirror for Princes. The Qabūs-Nāma. Translated by Reuben Levy. London: Cresset, 1951.

Kalila and Dimna. Retold by Ramsay Wood. New York: Alfred A Knopf, 1980.

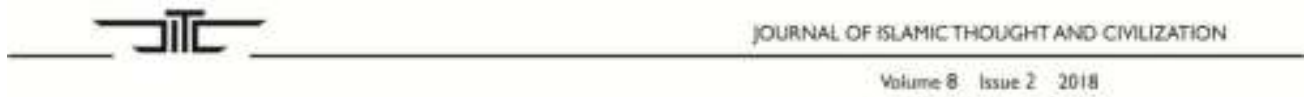


Zartman, Using Historical Islamic Sources to Promote Ethical Character

Kashifi, Husain Vaiz. Akhlāk-i-Muhsini (The Morals of the Beneficent). Translated by Henry George Keene. Hertford: Stephen Austen, 1750.

Kassis, Riad Aziz. The Book of Proverbs and Arabic Proverbial Works. Boston: Brill, 1999.

Kechichian, Joseph A. "Abdullah Ibn Al Muqaffa: Words of Wisdom for the Kings." Gulf News, October 17, 2013. http://gulfnews.com/life-style/general/abdullahibn-al-muqaffa-words-of-wisdom-for-the-kings-1.1244087.

Marlow, Louise. Hierarchy and Egalitarianism in Islamic Thought. Cambridge: Cambridge University Press, 1997.

Miskawayh, Abu 'Ali Ahmad ibn Muhammad Ibn Yaqub. The Refinement of Character (Tahdhīb al-Akhlāq). Translated by Constantine K Zurayk. Chicago: Great Books of the Islamic World, 2002.

al-Mulk, Nizām. The Book of Government or Rules for Kings: The Siyar al-Mulūk or Siyasat-namah. Translated by Hubert Darke. London: Routledge and Kegan Paul, 1978.

Omar, Mohd Nasir. "Ethics in Islam: A Brief Survey." The Social Sciences 8, no. 5 (2013): 387-392.

Orfali, Bilal, and Ramzi Baalbaki. "Introduction.” In The Book of Noble Character, Critical Edition of Makarim al-Akhlāq wa-mahāsin al-adab wa bada'I al Awsāf wa-ghara 'ib al-Tashbihāt, attributed to Abu Mansur al-Tha'alibi (d. 429/1039). Edited by Bilal Orfali and Ramzi Baalbaki. Boston: Brill, 2015.

Sadi, Muslih-ud-din. Sa'di's Scroll of Wisdom. Translation and Introduction by Arthur N. Wollaston. London: John Murray, 1906.

Shahid, Irfan. “Arabic Literature.” In The Cambridge History of Islam. Vol 2. Edited by P. M. Holt, Ann K. S. Lambton, and Bernard Lewis. Cambridge: Cambridge University Press, 1970.

Shukri, M. A. M. "Towards an Islamic Theory of Literature.” Islamic Studies 31, no. 4 (1992).

Sperl, Stefan. "Man's 'Hollow Core': Ethics and Aesthetics in Hadith Literature and Classical Arabic Adab." Bulletin of SOAS 70, no. 3 (2007): 459-486.

Starr, Frederick S. Lost Enlightenment: Central Asia's Golden Age from the Arab Conquest to Tamerlane. Princeton: Princeton University Press, 2013.

Subtelny, Maria E. "A Late Medieval Persian Summa on Ethics: Kashifi's Akhlāk-i Muhsinı." Iranian Studies 36, no. 4 (Dec 2003): 601-614.

The Book of Character. Edited by Camille Adams Helminski. Bath, England: The Book Foundation, 2004

“The Persian Sensation: 'The Rubáiyát of Omar Khayyám' in the West.” Austin, TX:

Harry Ransom Center, University of Texas, 2009.

http://www.hrc.utexas.edu/exhibitions/ 2009/rubaiyat/

Van Ruymbeke, Christine. "The Kalila wa Dimna and Rūmi: That was the Husk and this is the Kernel." Mawlana Rümi Review 4 (2013): 85-105. 
Zartman, Using Historical Islamic Sources to Promote Ethical Character

— Kashefi's Anvar-e Sohayli: Rewriting Kalila Wa-Dimna in Timurid Herat. Boston: Brill, 2016.

Webster, Sheila K. "Spicing the Conversation: The Development of Proverbs and its Role in Arab Culture." Al-Mashriq 2, no. 6 (September 2003). http://www.syriawide.com/spicing.html.

Yar-Shater, E. "Persian Literature." In The Cambridge History of Islam. Vol 2. Edited by P. M. Holt, Ann K. S. Lambton, and Bernard Lewis.

Cambridge: Cambridge University Press, 1970.

Zurayk, Constantine K. "Preface." In The Refinement of Character (Tahdhīb alAkhlāq).

Beirut: American University of Beirut, 2002. 